\title{
The Relationship between Corporate Strategy and Enterprise Risk Management: Evidence from Canada
}

\author{
Walid Ben-Amar ${ }^{1}$, Ameur Boujenoui ${ }^{1} \&$ Daniel Zéghal ${ }^{1}$ \\ ${ }^{1}$ Telfer School of Management, University of Ottawa, Ottawa, Canada \\ Correspondence: Walid Ben-Amar, Telfer School of Management, University of Ottawa, Ottawa, Canada. E-mail: \\ benamar@telfer.uottawa.ca \\ Received: November 15, 2013 \\ Accepted: December 2, $2013 \quad$ Online Published: February 15, 2014 \\ doi:10.5430/jms.v5n1p1 \\ URL: http://dx.doi.org/10.5430/jms.v5n1p1
}

We gratefully acknowledge the financial support of the CGA-Canada Accounting and Governance Research Centre and the Telfer School of Management Research Fund.

\begin{abstract}
In a context of high competition and economic turmoil, companies are faced with a whole array of financial, strategic and operational risks. To better understand and face repercussions on their activities, companies increasingly adopt integrated risk management systems. The objective of this study is to examine the link between the firm's corporate strategic choices and its risk management approach. Specifically, this paper investigates whether the firm's corporate strategy affects its level of risk exposure, the perception of risk consequences as well as its risk management strategy. Based on a sample of 110 non financial firms listed on the Toronto Stock exchange, we find that risk exposure level, perception of risk consequences and risk management strategy vary according to the firm's business sector. Our results show also that a firm's corporate strategy is a key determinant of its risk management approach.
\end{abstract}

Keywords: risk management, risk exposure, corporate strategy, diversification

\section{Introduction}

More than ever before, in the current context of market globalization, companies are faced with numerous and varied risks which they cannot ignore when making decisions, whether strategic or operational. In fact, faced with so many economic, political, technological and ecological mutations, companies are faced with a vast array of risks which they must identify and try to manage if they want to ensure their survival. The concepts of strategy and risk are linked together - linked both in theory as in practice. Both constitute the cornerstone of decisions within companies. But where establishing a strategy involves choices to be made by senior executives, Caldwell (2012) posits that risks are inherent to any strategic option. To that end, the company's management and its board of directors should analyze the links between various strategic options and the risks they entail when entering into a strategic planning process (Smith, 2012).

Traditional approaches to risk management were defined by their fragmentation and partial solutions. Today, more and more decision makers are convinced that such approaches need to be revisited (Hoyt and Liebenberg, 2011). An integrated Enterprise Risk Management approach would be more appropriate to face management challenges in this new economy characterized by ever increasing volatility and uncertainties (McShane et al., 2011). Enterprise Risk Management (ERM) is a rigorous approach to analyze all risks which may prevent a company from reaching its strategic objectives. Hoyt and Liebenberg (2011) suggest that ERM might reduce the volatility of earnings and stock prices and lower the cost of issuing equity while fostering a better synergy between the various risk management initiatives within the firm. All these factors should have a positive effect of integrated risk management on the company's value.

However, academic research to date only gets mixed results when examining the relationship between ERM and a company's performance (Smithson and Simkins, 2005; Gordon et al., 2009; Razali and Tahir, 2011; McShane et al., 2011). Gordon et al. (2009) suggest that the relationship between ERM and the company's performance is contingent upon more factors specific to the company, including the complexity of its activities (the number of its business segments). Furthermore, numerous previous studies have been conducted on integrated enterprise risk management, especially on risk disclosure (Linsley and Shrives, 2006; Dobler, 2008; ICAEW, 2011), but to the best of our knowledge, no prior study has explored the link between a company's strategic choices and ERM. 
Thus the objective of our research is to analyze relationships between a company's strategic options and its approach to risk management. More specifically, our study will examine if a company strategy affects its exposure to risks, the perception of the consequences of those risks and, finally, its risk management strategy. Our study is based on a sample of 110 non-financial companies listed on the Toronto Stock Exchange. Using a content analysis of information extracted from annual reports, we identified risks which we then codified according to three dimensions, namely exposure to risks, consequences of risk materialization and risk management strategies. We also identified business sectors for each company as well as their main corporate strategic orientations.

The rest of the paper is organized as follows: the next section reviews the relevant literature on various strategic orientations as well as on enterprise risk management; the third section explains our research methodology; the fourth section presents the main results of the study and is followed by a conclusion.

\section{Literature Review}

\subsection{Corporate Strategic Orientations}

In the field of strategic management, numerous studies have been dedicated to enterprise strategy at what is called the corporate level (Ansoff, 1965; Rumelt, 1974). This level establishes the company's perimeter, and as such, the industrial sectors in which its senior executives would like to see the company operate and grow (Ansoff, 1965). To that end, a company may end up evolving within a single business unit whereas another may have two or more units in various sectors and/or markets. Furthermore, these separate units may report to the chain of value, thus making the company a vertically-integrated one just as they may be the various components of the portfolio of a diversified company with varied business segments either related or entirely unrelated. In the case of a diversified company, top management will also be concerned with choosing how to manage those units in order to maximize the company's overall performance (Chandler, 1994). Attention then turns to the organizational structure and management processes, and more particularly to the system in place to evaluate the performance of each unit within the company's portfolio.

Collis and Montgomery (2005), when defining corporate strategy as a modification of the company's activities, put emphasis on the value creation through the configuration of the company's activity portfolio and the coordination between the various business units. The allocation of resources between those units also constitutes an important strategic dimension at that level. In order to ensure the growth and development of their company, and especially its survival, senior executives have a choice between a strategy of development within the same sphere of activity, or specialization, a vertical integration, and a strategy of diversification within two or more business sectors.

A company which opts for a strategy of specialization operates within a single business sector which represents a significant proportion of its sales. Rumelt (1974) qualified this type of company as a "single-business" company where $95 \%$ or more of its total sales stem from that unit. Far from being the case for only those companies in their first development phase, Rumelt (1974) has found that this group represented $42 \%$ of all Fortune 500 companies in 1949, and $14.4 \%$ of them in 1974. At the beginning of the new millennium, this percentage was thought to be between 5 and $7 \%$.

According to Ansoff (1965), a company which opts for a specialization strategy, will focus on one business segment and supply products or services to customers it has identified. Later on, in order to ensure its growth, it will have to look for new products and/or services, or new markets, but only within its business sector. That way, it will either have to expand its line of products or services within this area, offer new products or services within an existing brand, or expand geographically while offering the same products or services to its new customers. By pursuing a strategy of specialization, the company might acquire a large market share, see a reduction in its costs, benefit through economies of scale and from the results of experience while improving its productivity and, in the end, ensuring better profitability.

It goes without saying that this type of strategy is not without risks. Economic slow-downs, important changes within the customers' lifestyle, the industry reaching maturity or even a radical change in technological advances rendering those products or services obsolete may disturb and even undermine the demand for the company's products or services, sending it in a prolonged crisis which might threaten its survival.

The second strategic option a company could opt for, at the corporate level, is that of vertical integration. Strategic management scholars (Mpoyi, 200; Davis and Duhaime, 1992) posit that in addition to ensuring its production stage, a company which adopts such an orientation also ensures its supply (upstream integration) for example, or that of the distribution of its product while getting as close as possible to its end customer (downstream integration) or it can do both at the same time (more or less total vertical integration). It could also opt for a horizontal integration by acquiring one or more competitors who manufacture similar products. This strategy aims at making economies of scale and obtaining a negotiating power with suppliers and/or distributors, and clients. Senior executives who choose this strategic option are concerned with knowing up to what point they wish the company to control the production of its inputs or its suppliers as well as the distribution of its outputs. In the end, it comes down to making a choice between 
producing in-house goods and services which the company would need, or calling upon the markets based on the criteria of transaction cost reduction (Williamson, 1981). The risks, with this integration strategy, is that it limits the firm's flexibility and response time since it could have a negative effect on the company in times of recession or of a slowing down of final demand in its industry.

The third strategic option, at the corporate level, would be business diversification. This strategic option was one of the most examined areas of research in strategic management (Hoskisson and Hitt, 1990; Wan, Hoskisson, Short and Yiu, 2011). Rumelt (1974) was a pioneer in this field. After his ground-breaking work, numerous researchers examined diversification in order to explain differences in the performance and growth of companies, with a particular focus on the effects of related and unrelated diversification on firm performance (Miller, 2006; Robins and Wiersema, 1995).

For a company's senior executives, diversification means entering new business sectors where the company is not currently present and developing or acquiring skills in order to operate within these business sectors. Reinvesting available capital, the need to establish the firm's positioning in a fickle market (by entering complementary sectors for example), the need to redeploy in new business segments offering better growth opportunities than the current ones (which have probably matured) and the need to find other activities to ensure the company's survival in the face of problematic competing positioning of other business units are among the reasons given for such a choice. If senior executives have often pursued diversification strategies through sharing and reducing business risks while hoping to improve the company's overall profitability, they could not ignore the risks specific to this strategic option. In fact, when a company enters new markets and offers new products, it may end up in a difficult, and even in a very tenuous competitive situation among which are elevated costs and aggressive reactions from competitors in the field.

Smith (2012) suggests that senior executives take into account certain risk factors in their strategic choice decisions. However, other risks may happen with unforeseen events or circumstances. Corporate reaction to those risks will depend on managers' risk tolerance level and on the measures undertaken to manage them.

\subsection{Enterprise Risk Management: Definition, Determinants and Value Creation}

When trying to implement their strategic choices, companies are faced with an ever-growing competition while having to stay alert to opportunities and ready to defeat environmental threats. Senior executives thus have only one course of action: choose the right strategy whether at the corporate level or for each of its business segments. It goes without saying that such choices include a certain number of risks which affect the company's ability to reach its objectives and ensure its survival. What is at stake here is the effects of uncertainty upon objectives established by a company or one of its components. Prior research (Dia and Zéghal 2008; McShane et al., 2011; Razali and Tahir, 2011) clearly shows that risks have evolved in number and in intensity and their management has become more and more complex but indispensable since what is at stake here is the survival of the company itself. The presence of risks within companies' environment is natural. It has always existed and executives choose their course of action in relation with the palatability of each of those risks.

There is no doubt that there exists, today, a relation between the growth of a company or one of its divisions, the risks involved and the results obtained. Consequently, senior executives are called upon to identify and evaluate risks and establish acceptable levels which might be compatible with the company objectives. Traditionally, all the risks identified by executives were treated independently from one another by specialists in the various departments and entities of the company (Beasley et al., 2005). This was called "risk management in silo," where interrelations were not taken into consideration and their effects were completely ignored.

Nowadays, with more and more complex and interrelated risks, senior executives have to mobilize vast resources and take their time to identify a whole array of risks before proceeding to their evaluation and choosing an adequate solution to manage them. In the identification phase, they often rely on a classification by category. For example, Caldwell (2012) makes a distinction between various categories of risks: strategic, operational, financial, leadership, non-conformity, unforeseeable, loss of reputation and external. Lajili and Zéghal (2005) rather proposed a much larger classification while specifying the detailed content of each identified category of risks (financial, market, environmental, regulation, operational, suppliers, natural resources, political, technological, climate, seasonal and cyclical risks).

Since the middle of the 1990s, senior executives in North America, in Europe and elsewhere in the world, have started looking at risk management from a holistic point of view. It is in that environment that Enterprise Risk Management (ERM) has appeared and continues to evolve because of its positive impacts generally expected on performance and on the way in which senior executives look at risks. This ERM concept has rapidly become largely accepted by most executives.

Integrated risk management means not only identifying and evaluating risks which may individually affect the attainment of the firm's objectives, but also their overall approach and the implementation of strategies for the company as a whole in order to manage them. In other words, it may be defined as an overall, integrated approach 
through which a company, whatever its industrial sector, evaluates, controls, operates, finances and oversees risks, wherever they may come from, in order to reach its objectives and increase its short and long-term value for its stakeholders (Razali and Tahir, 2011; Caldwell, 2012).

The main objective of ERM is to identify, manage and mitigate risks and to seize all opportunities for the whole company. It is an approach which provides a risk management framework articulated around identifying particular circumstances or events which may have an influence on the company's objectives, evaluating the occurrence of risks and their prevalence, identifying responses or strategies to attenuate them and establishing a monitoring process. These different ways of looking at IERM were explained by the Committee of Sponsoring organizations of the Treadway Commission (COSO, 2004) in its report "The Enterprise Risk Management - Integrated Framework" where enterprise risk management is defined as a "process, effected by an entity's board of directors, management and other personnel, applied in strategy setting and across the enterprise, designed to identify potential events that may affect the entity, and manage risk to be within its risk appetite, to provide reasonable assurance regarding the achievement of entity's objectives" (COSO, 2004, page 2).

ERM is therefore a true paradigmatic shift noticed in companies where a company senior executives wish to reposition themselves with regard to risk. In these companies, rather than concentrating on one risk at a time, senior executives look at all events and actions which may keep the company from attaining its objectives and which have an incidence on the company's value. Although it may not always be possible to control the effects of those various risks, their causes can be identified and managed in relation with the company overall objectives. For that, senior executives need to have a thorough knowledge of all potential risks, their relationship to one another and their impacts on the company objectives.

Prior research in finance has studied more thoroughly the determinants of the implementation of integrated risk management and the relationship between integrated risk management and performance. The first series of studies (Liebenberg and Hoyt, 2003; Beasley et al., 2005; Pagash and Warr, 2011) tried to identify the explanatory factors of adopting an IERM system. Beasley et al. (2005) thought that the presence of a Chief Risk Officer at upper-management level, the size of the company and its belonging to the financial sector promoted the adoption of a risk management system. Pagash and Warr (2011) observed that the debt level, the volatility of accounting results and a variable remuneration for the CEO depending on the volatility of stock prices had a positive influence on the probability of nominating a Chief Risk Officer within the company.

Another series of studies looked at the relationship between risk management and performance (Allayannis and Weston, 2001; Beasley et al., 2008; Gordon et al., 2009; McShane et al., 2011; Hoyt and Lienberg, 2011). Allayannis and Weston (2001) showed that using a hedging strategy against currency risk gave the company a value premium of $5 \%$ with regard to other companies who did not hedge against such a risk. Beasley et al. (2008) reported a positive stock market reaction at the announcement of the nomination of a Chief Risk Officer in non-financial companies. In contrast, they did not report such a positive effect for financial firms. Gordon et al. (2009) found that the relation between ERM and firm performance is contingent on a number of firm-specific factors which include uncertainties in the company's environment, competition within its industrial sector, complexity of its activities, its size and the control exerted by its board of directors. Finally, while Hoyt and Liebenberg (2011) found a positive relationship between adopting an integrated risk management system and the value of insurance companies, McShane et al. (2011) could not come to the same conclusion. It should be noted that the divergence of results between those studies may be attributed, among other factors, to the adoption of samples from different industrial sectors, to the quality of information available on integrated risk management (Lajili and Zeghal, 2005) and to the use of distinct measurements for those risks.

Research on enterprise risk management has become more important in the past few years. Numerous studies explored risk disclosure practices in publicly listed companies and the link between risk management practices and firm performance. However, a company's strategic choices and risk management were seldom studied. This gave rise to our main area of research: the study of the empirical link which may exist between corporate strategies adopted by Canadian companies and their approach to integrated enterprise risk management. It is generally recognized that different strategies require different financial, material and human resources. Furthermore, they require different types of priorities and control systems as well as different success factors. This allows us to anticipate that different strategies would provide differences with regard to exposure to risk, to perception of the consequences of risk materialization and to strategies to be adopted in order to mitigate these risks.

\section{Methodology}

\subsection{Sample}

Our study is based on data collected for a sample of 110 non-financial companies listed on the Toronto Stock Exchange included in the list of the 200 companies on the Globe and Mail's Report on Business for the year 2007 with available annual reports and financial, business risks and corporate strategy data.. Table 1 shows the sample firms' distribution 
by main industrial sectors. $46.6 \%$ of our sample firms belong to the resources, whereas manufacturing and services sectors account for $24.4 \%$ and $29 \%$ respectively. This structure of our sample reflects the characteristics of the Canadian economy in which natural resources (oil \& gas, pulp \& paper) is a dominant business sector.

Table 1. Sample distribution by industry

\begin{tabular}{|c|c|c|c|c|}
\hline & NAICS & $\begin{array}{l}\text { Number of } \\
\text { enterprises }\end{array}$ & $\%$ from Total & $\begin{array}{l}\% \text { from each } \\
\text { group }\end{array}$ \\
\hline \multirow{4}{*}{ I. Resources } & 113 & 4 & 3.7 & 7.8 \\
\hline & 211 & 22 & 20.1 & 43.2 \\
\hline & 212 & 21 & 19.1 & 41.2 \\
\hline & 213 & 4 & 3.7 & 7.8 \\
\hline Total & & 51 & 46.6 & 100 \\
\hline \multirow{10}{*}{ II. Manufacturing } & 311 & 2 & 1.8 & 7.4 \\
\hline & 312 & 2 & 1.8 & 7.4 \\
\hline & 315 & 1 & 0.9 & 3.7 \\
\hline & 322 & 3 & 2.7 & 11.1 \\
\hline & 325 & 4 & 3.7 & 14.8 \\
\hline & 333 & 3 & 2.7 & 11.1 \\
\hline & 334 & 2 & 1.8 & 7.4 \\
\hline & 335 & 2 & 1.8 & 7.4 \\
\hline & 336 & 5 & 4.5 & 18.5 \\
\hline & 339 & 3 & 2.7 & 11.1 \\
\hline Total & & 27 & 24.4 & 100 \\
\hline \multirow{14}{*}{ III. Services } & 221 & 3 & 2.7 & 9.4 \\
\hline & 236 & 1 & 0.9 & 3.1 \\
\hline & 445 & 5 & 4.6 & 15.5 \\
\hline & 446 & 2 & 1.8 & 6.3 \\
\hline & 448 & 2 & 1.8 & 6.3 \\
\hline & 452 & 2 & 1.8 & 6.3 \\
\hline & 481 & 2 & 1.8 & 6.3 \\
\hline & 486 & 1 & 0.9 & 3.1 \\
\hline & 512 & 2 & 1.8 & 6.3 \\
\hline & 515 & 3 & 2.7 & 9.4 \\
\hline & 517 & 4 & 3.7 & 12.4 \\
\hline & 531 & 1 & 0.9 & 3.1 \\
\hline & 541 & 3 & 2.7 & 9.4 \\
\hline & 722 & 1 & 0.9 & 3.1 \\
\hline Total & & 32 & 29.0 & 100 \\
\hline Total sample & & 110 & 100 & 100 \\
\hline
\end{tabular}

\subsection{Variable Definition}

The two major variables in this study are strategic choices and integrated enterprise risk management. Both are measured with the content analysis methodology for which we have analyzed relevant sections of the firms' annual reports, which we then codified with two coding frames, one for each of the two variables previously developed on the basis of prior research. Data collection was done in three stages. First, we collected annual reports for fiscal year ending in 2007 from the SEDAR electronic database (www.sedar.com). Data for year 2007 was used to eliminate the potential impact of the financial crisis of 2008 on financial data and risk management practices.

Examining the reports allowed us to extract information related to risk management. By adopting the approach used in previous studies who used this analytical framework (Lajili and Zéghal, 2005; Dia and Zéghal, 2008), a graduate student familiar with content analysis methodology was trained by one of the authors to codify the information. He had to start by identifying the risk category for each company by referring to an already-established list. In this study, we have kept the same risk classification as Lajili and Zéghal (2005) and Dia and Zéghal (2008) by grouping risks in three large categories. Financial risks include currency, credit, interest rate risk as well as the risk related to the value of financial instruments. Operational risks include environmental risk, natural resources risk, and risks related to 
operations and suppliers as well as technological risk. Finally, business risks (also called strategic risks) include market risks, risks related to climate, seasons and regulations, as well as political risks and those associated with cyclicality.

For each type of identified risk, we adopted the risk analysis map suggested in current literature (AICPA/CICA, 1999) to measure the level of a firm's exposure (Rare, Improbable, Possible, Rare, Probable and Definite), the intensity of consequences of risk materialization (Catastrophic, Major, Moderate, Minor, Insignificant) and the type of strategy used to face the risk (Accept the risk, Transfer, Reduce and Avoid). This codification was done by the same graduate student. In order to ensure reliability of the coding procedure, the first ten cases were codified by both the student and one of the authors.

The second stage was to collect accounting and financial data for fiscal year ending in 2007. This information was related to total assets, debt ratio, return on equity (ROE) and share market value, among others. These were extracted from the STOCK-GUIDE electronic database. In the cases of mergers, closures and lack of data, those companies were discarded. For the third stage, one of the authors, who is a strategic management professor, attentively read all the annual reports in order to identify and codify the corporate strategy used for each one of the 110 companies within our sample.

\section{Results}

\subsection{Descriptive Statistics}

Table 2 presents descriptive statistics for a few financial characteristics (market value, size of assets, debt ratio and return on equity) of the sample firms as well as for companies within each of the industrial sectors.

Table 2. Financial variables

\begin{tabular}{lcrrrrrr}
\hline & N & \multicolumn{1}{c}{ Min } & \multicolumn{1}{c}{ Max } & Median & Average & $\begin{array}{c}\text { Standard } \\
\text { Deviation }\end{array}$ \\
\hline \multicolumn{1}{c}{ Panel A: Total Sample } & & & & & & \\
\hline Market value $(000,000 \$)$ & 110 & 23 & 43486 & 1773 & 5639 & 9519 \\
\hline Total Assets $(000,000 \$)$ & 110 & 63 & 5755 & 24906 & 6980 & 10265 \\
\hline Debt/Equity & 110 & 0.02 & 6.59 & 0.45 & 0.77 & 0.92 \\
\hline Return On Equity (\%) & 110 & -122.92 & 78.62 & 10.45 & 2.24 & 32.15 \\
\hline
\end{tabular}

\begin{tabular}{lrrrrrr}
\multicolumn{1}{c}{ Panel B: Resources } & \multicolumn{1}{c}{} \\
\hline Market value $(000,000 \$)$ & 51 & 110 & 43358 & 1440 & 6814 & 11270 \\
\hline Total Assets $(000,000 \$)$ & 51 & 255 & 57547 & 1852 & 7555 & 12549 \\
\hline Debt/Equity & 51 & 0.02 & 2.83 & 0.34 & 0.46 & 0.51 \\
\hline Return On Equity (\%) & 51 & -109.91 & 36.82 & 4.8 & -2.00 & 31.06 \\
\hline
\end{tabular}

\begin{tabular}{|c|c|c|c|c|c|c|}
\hline Panel C: Manufacturing & & & & & & \\
\hline Market value $(000,000 \$)$ & 27 & 41 & 43486 & 1393 & 4667 & 9900 \\
\hline Total Assets $(000,000 \$)$ & 27 & 63 & 26135 & 2676 & 5025 & 5963 \\
\hline Debt/Equity & 27 & 0.06 & 3.89 & 0.65 & 0.95 & 0.86 \\
\hline Return On Equity (\%) & 27 & -90.86 & 78.62 & 9.92 & 9.25 & 33.3 \\
\hline
\end{tabular}

\begin{tabular}{lrrrrrr}
\hline Panel D: Services & & & & & & \\
\hline Market value $(000,000 \$)$ & 32 & 23 & 19032 & 2491 & 4585 & 5226 \\
\hline Total Assets $(000,000 \$)$ & 32 & 406 & 39414 & 3784 & 7712 & 9069 \\
\hline Debt/Equity & 32 & 0.03 & 6.59 & 0.69 & 1.1 & 1.27 \\
\hline Return On Equity (\%) & 32 & -122.92 & 31.61 & 13.66 & 3.08 & 32.78 \\
\hline
\end{tabular}


Table 3 shows the distribution of corporate strategic options preferred by the companies within our sample in each of the three industrial sectors. Specialization strategy was the option chosen more often by all companies whatever the business sector they belonged to $(78.2 \%)$. In the resources sector, it was preferred by $84.4 \%$ of entities; in the services sectors, $78.1 \%$ of them opted for specialization whereas $18.8 \%$ choose the diversification option. It is in the manufacturing sector that we observed the largest proportion of companies who chose diversification (26\%) as their strategic option; however, $66.6 \%$ nevertheless chose the specialization option for their activities.

Table 3. Corporate strategic choices by industry

\begin{tabular}{rrrrr}
\hline & \multicolumn{1}{l}{ Resources } & Manufacturing & \multicolumn{1}{l}{ Services } & \multicolumn{1}{c}{ Total } \\
\hline Specialization & & & & \\
\hline Diversification & $43(84.4)$ & $18(66.6)$ & $25(78.1)$ & $\mathbf{8 6}$ (78.2) \\
\hline Vertical Integration & $4(7.8)$ & $7(26.0)$ & $6(18.8)$ & $\mathbf{1 7}(\mathbf{1 5 . 4 )}$ \\
\hline Total & $4(7.8)$ & $2(7.4)$ & $1(3.1)$ & $\mathbf{7 ( 6 . 4 )}$ \\
\hline
\end{tabular}

\subsection{Enterprise Risk Management Analysis by Industrial Sector}

This first analysis aims to examine whether risk management practices differ between the industries (resources, manufacturing and services) in our sample. We distinguish between three main business risks categories namely financial, operational and strategic risks. Risk elements within each category appear in the first columns of each table as 4-a, 4-b and 4-c. As defined in the process of enterprise risk management, we analyzed the following aspects: i) risk exposure, ii) consequences of risk materialization and iii) risk management strategies.

\subsubsection{Risk Exposure Analysis by Industrial Sector}

Table 4a shows risk exposure profiles by industrial sector. The resources sector seems more exposed to financial risk than to the other two categories (operational and strategic). In financial risks, the currency risk and that of interest rates are those where exposure is greater for this industry. It should also be noted that in terms of strategic risks, natural resources companies perceive a high risk exposure to market and governmental regulation risks. In the light of the current debate on greenhouse gas emission through the development of oil sands in Alberta, companies may fear a tightening-up of regulations which may increase possible non-compliance costs.

Companies in the industrial sector also seem more exposed to financial risks than to operational or strategic risks. Currency and market risks are the highest average levels among risk categories. Finally, in the service sector, we noticed a risk exposure profile which was different from the other two sectors. In fact, even if the financial risk is the risk category to which the service sector is more exposed, the sector seems more exposed to strategic risks than to operational ones. Market and governmental regulation risks are those which present the highest average levels among risk categories in the whole service sector.

Finally, for the three risk categories (financial, operational and strategic), the resources sector seems to show the following averages: 4.60, 4.18 and 4.17 respectively, whereas the industrial sector shows averages as follows: 4.69, 4.11 and 3.91 respectively. Finally, in the services sector, averages are respectively 4.42, 3.69 and 3.76. From these averages, it is clear that the service sector is less exposed to risks than the resource sector or the manufacturing one. 
Table 4a. Analysis of risk exposure by industry

\section{Panel A - Resources}

\section{Panel B- Manufacturing}

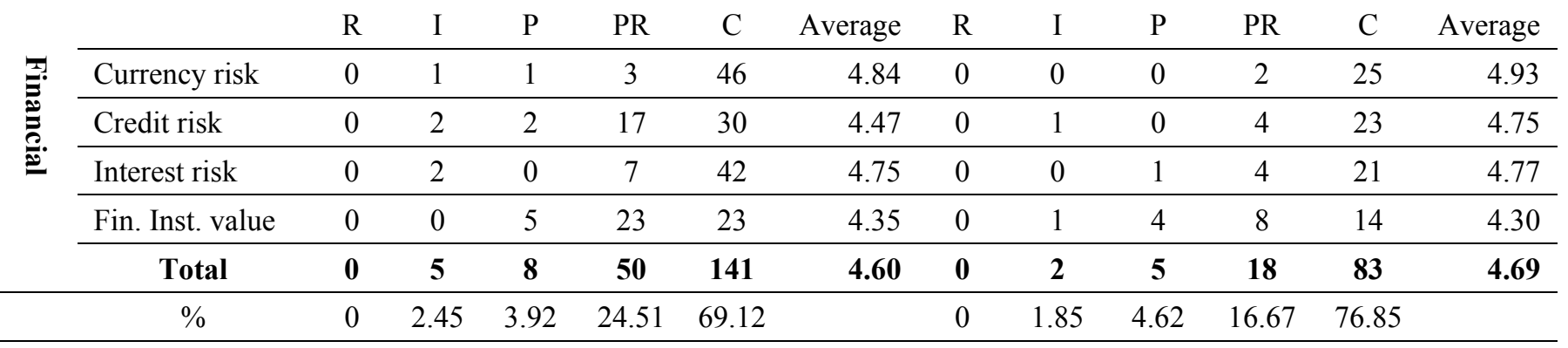

\begin{tabular}{|c|c|c|c|c|c|c|c|c|c|c|c|c|c|}
\hline \multirow{7}{*}{ 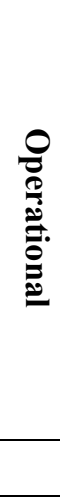 } & $\begin{array}{l}\text { Environment } \\
\text { risk }\end{array}$ & 0 & 0 & 3 & 5 & 43 & 4.78 & 1 & 1 & 1 & 6 & 18 & 4.44 \\
\hline & $\begin{array}{l}\text { Natural } \\
\text { resources }\end{array}$ & 1 & 7 & 11 & 25 & 7 & 3.59 & 1 & 6 & 9 & 8 & 3 & 3.22 \\
\hline & Operational risk & 0 & 1 & 10 & 2 & 38 & 4.51 & 0 & 1 & 5 & 5 & 17 & 4.36 \\
\hline & Suppliers & 0 & 8 & 15 & 22 & 6 & 3.51 & 0 & 0 & 5 & 14 & 7 & 4.08 \\
\hline & Technology & 0 & 3 & 2 & 12 & 34 & 4.51 & 0 & 1 & 3 & 6 & 17 & 4.44 \\
\hline & Total & 1 & 19 & 41 & 66 & 128 & 4.18 & 2 & 9 & 23 & 39 & 62 & 4.11 \\
\hline & $\%$ & 0.39 & 7.45 & 16.08 & 25.88 & 50.20 & & 1.48 & 6.67 & 17.04 & 28.89 & 45.93 & \\
\hline \multirow{8}{*}{ 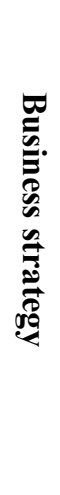 } & Market risk & 0 & 1 & 1 & 0 & 49 & 4.90 & 0 & 0 & 0 & 2 & 25 & 4.93 \\
\hline & Weather risk & 0 & 2 & 6 & 28 & 15 & 4.10 & 3 & 13 & 4 & 5 & 2 & 2.63 \\
\hline & Seasonality & 2 & 9 & 22 & 7 & 11 & 3.31 & 1 & 8 & 5 & 6 & 7 & 3.37 \\
\hline & $\begin{array}{l}\text { Government } \\
\text { regulation }\end{array}$ & 0 & 0 & 0 & 4 & 47 & 4.92 & 0 & 0 & 1 & 6 & 20 & 4.70 \\
\hline & Political risk & 0 & 0 & 4 & 10 & 37 & 4.65 & 0 & 0 & 3 & 8 & 16 & 4.48 \\
\hline & cyclicality & 2 & 18 & 16 & 2 & 13 & 3.12 & 0 & 9 & 5 & 8 & 5 & 3.33 \\
\hline & Total & 4 & 30 & 49 & 51 & 172 & 4.17 & 4 & 30 & 18 & 35 & 75 & 3.91 \\
\hline & $\%$ & 1.31 & 9.80 & 16.01 & 16.67 & 56.21 & & 2.47 & 18.25 & 11.11 & 21.60 & 46.30 & \\
\hline
\end{tabular}

$\mathrm{R}=$ Rare (1), I=Improbable (2), $\mathrm{P}=$ Possible (3), $\mathrm{PR}=$ Probable (4), $\mathrm{C}=$ Certain (5) 
Table 4a. Analysis of risk exposure by industry (continued)

\section{Panel C- Services}

\begin{tabular}{|c|c|c|c|c|c|c|c|}
\hline \multirow{7}{*}{ 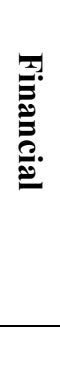 } & & $\mathrm{R}$ & I & $\mathrm{P}$ & PR & $\mathrm{C}$ & Average \\
\hline & Currency risk & 0 & 1 & 3 & 3 & 25 & 4.63 \\
\hline & Credit risk & 0 & 6 & 1 & 6 & 19 & 4.19 \\
\hline & Interest risk & 0 & 1 & 10 & 2 & 29 & 4.40 \\
\hline & Fin. Inst. value & 0 & 0 & 4 & 9 & 19 & 4.47 \\
\hline & Total & $\mathbf{0}$ & 8 & 18 & 20 & 92 & 4.42 \\
\hline & $\%$ & 0 & 5.80 & 13.04 & 14.49 & 66.67 & \\
\hline
\end{tabular}

\begin{tabular}{cccccccc}
\hline & Environment risk & 1 & 7 & 3 & 7 & 14 & 3.81 \\
\cline { 2 - 8 } & Natural resources & 2 & 21 & 5 & 4 & 0 & 2.34 \\
\cline { 2 - 8 } & Operational risk & 0 & 2 & 11 & 5 & 14 & 3.97 \\
\hline \multirow{2}{*}{ Suppliers } & 0 & 4 & 8 & 14 & 6 & 3.69 \\
\hline Technology & 0 & 1 & 2 & 4 & 25 & 4.66 \\
\hline Total & $\mathbf{3}$ & $\mathbf{3 5}$ & $\mathbf{2 9}$ & $\mathbf{3 4}$ & $\mathbf{5 9}$ & $\mathbf{3 . 6 9}$ \\
\hline$\%$ & 1.88 & 21.88 & 18.13 & 21.25 & 36.88 &
\end{tabular}

\begin{tabular}{|c|c|c|c|c|c|c|c|}
\hline \multirow{8}{*}{ 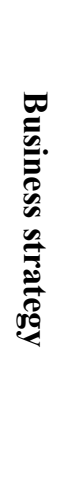 } & Market risk & 0 & 0 & 0 & 1 & 31 & 4.97 \\
\hline & Weather risk & 4 & 11 & 8 & 7 & 2 & 2.75 \\
\hline & Seasonality & 0 & 5 & 6 & 11 & 10 & 3.81 \\
\hline & $\begin{array}{l}\text { Government } \\
\text { regulation }\end{array}$ & 0 & 0 & 2 & 3 & 27 & 4.78 \\
\hline & Political risk & 1 & 3 & 8 & 9 & 11 & 3.81 \\
\hline & cyclicality & 0 & 26 & 2 & 1 & 3 & 2.41 \\
\hline & Total & 5 & 45 & 26 & 32 & 84 & 3.76 \\
\hline & $\%$ & 2.60 & 23.44 & 13.54 & 16.67 & 43.75 & \\
\hline
\end{tabular}

\subsubsection{Analysis of Risk Consequences by Industry}

Table $4 \mathrm{~b}$ shows an analysis of the consequences of risk materialization according to industrial sector. In the resources sector, approximately $46 \%$ of companies consider that the consequences of financial risks materialization are major whereas almost $50 \%$ of them perceive those consequences as moderate. The consequences of operational risks materialization are considered as major for $51 \%$ of companies, and even as catastrophic for $4 \%$ of them. Finally, the consequences of strategic risks are considered as moderate for $32 \%$ of companies and major for $45 \%$ of them.

Within the manufacturing sector, the consequences of financial risks materialization are perceived as major by $51 \%$ of companies and as catastrophic by $4 \%$ of them. The consequences of operational risks are considered as catastrophic for $7 \%$ of companies and major for $35 \%$ of them. Finally, the consequences of strategic risks are considered as major for $36 \%$ of companies in that sector. Finally, in the service sector, $54 \%$ of companies consider the consequences of financial risk materialization as major. Only $41 \%$ and $35 \%$ consider the consequences of operational and strategic risks as major. 
In general, for all categories of financial, operational and strategic risks and for the three sectors as a whole, exposure to risk is on average considered as moderate (3) and major (4) with a minimum average of 2.95 and a maximum average of 3.52. Overall, the results of this analysis suggest that the perception of risk materialization does not vary dramatically from one industry to another.

Table $4 \mathrm{~b}$. Analysis of perception of risk consequences by industry

Panel A - Resources

Panel B- Manufacturing

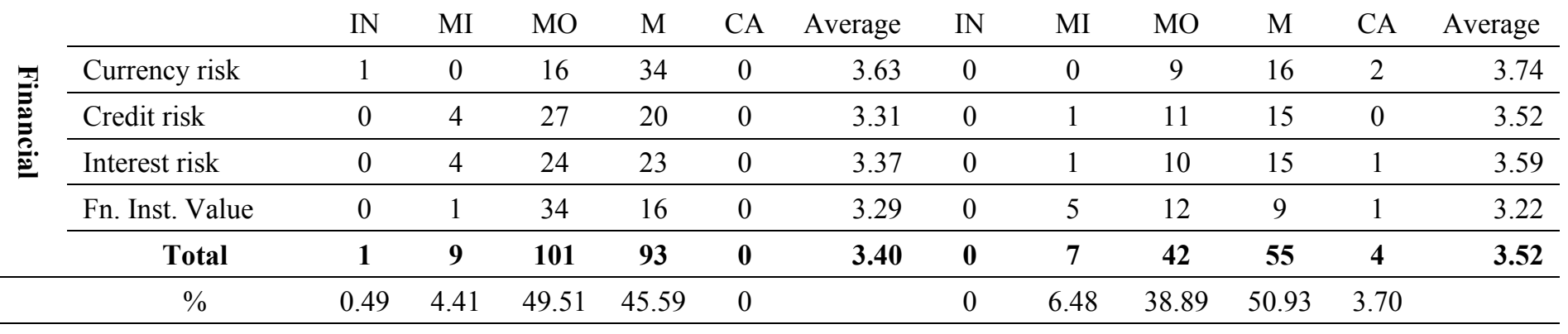

\begin{tabular}{|c|c|c|c|c|c|c|c|c|c|c|c|c|c|}
\hline \multirow{7}{*}{ 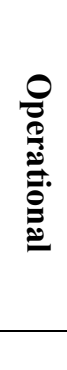 } & Environment risk & 0 & 1 & 21 & 29 & 0 & 3.55 & 2 & 1 & 10 & 13 & 1 & 3.37 \\
\hline & Natural resources & 6 & 6 & 10 & 29 & 0 & 3.22 & 6 & 5 & 11 & 3 & 2 & 2.63 \\
\hline & Operation risk & 1 & 1 & 8 & 33 & 8 & 3.90 & 1 & 2 & 6 & 7 & 1 & 3.29 \\
\hline & Suppliers & 8 & 7 & 22 & 12 & 2 & 2.86 & 0 & 2 & 14 & 8 & 3 & 3.44 \\
\hline & Technology & 3 & 0 & 22 & 26 & 0 & 3.39 & 0 & 4 & 8 & 13 & 2 & 3.48 \\
\hline & Total & 18 & 15 & 83 & 129 & 10 & 3.38 & 9 & 14 & 49 & 44 & 9 & 3.24 \\
\hline & $\%$ & 7.06 & 5.88 & 32.55 & 50.59 & 3.92 & & 7.20 & 11.20 & 39.20 & 35.20 & 7.20 & \\
\hline
\end{tabular}

\begin{tabular}{|c|c|c|c|c|c|c|c|c|c|c|c|c|c|}
\hline \multirow{9}{*}{ 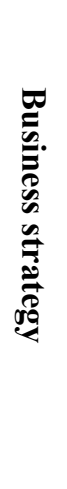 } & Market risk & 0 & 1 & 3 & 46 & 1 & 3.92 & 0 & 0 & 5 & 21 & 1 & 3.85 \\
\hline & Weather risk & 2 & 0 & 31 & 16 & 2 & 3.31 & 16 & 1 & 6 & 3 & 1 & 1.96 \\
\hline & Seasonality & 10 & 19 & 14 & 8 & 0 & 2.39 & 8 & 4 & 7 & 7 & 1 & 2.59 \\
\hline & Government & & & & & & & & & & & & \\
\hline & regulation & 0 & 0 & 21 & 30 & 0 & 3.59 & 0 & 2 & 14 & 11 & 0 & 3.33 \\
\hline & Political risk & 0 & 0 & 17 & 33 & 1 & 3.69 & 0 & 1 & 15 & 9 & 2 & 3.44 \\
\hline & Cyclicality & 17 & 16 & 11 & 6 & 1 & 2.18 & 8 & 5 & 6 & 8 & 0 & 2.52 \\
\hline & Total & 29 & 36 & 97 & 139 & 5 & 3.18 & 32 & 13 & 53 & 59 & 5 & 2.95 \\
\hline & $\%$ & 9.48 & 11.76 & 31.70 & 45.42 & 1.63 & & 19.75 & 8.02 & 32.72 & 36.42 & 3.09 & \\
\hline
\end{tabular}

$\mathrm{IN}=$ Insignificant (1), $\mathrm{MI}=$ Minor (2), $\mathrm{MO}=$ Moderate (3), $\mathrm{M}=$ Major (4), $\mathrm{CA}(5)=$ Catastrophic 
Table $4 b$. Analysis of perception of risk consequences by industry (continued)

\section{Panel C- Services}

\begin{tabular}{|c|c|c|c|c|c|c|c|}
\hline \multirow{7}{*}{. } & & IN & MI & MO & M & $\mathrm{CA}$ & Average \\
\hline & Currency risk & 1 & 4 & 10 & 17 & 0 & 3.34 \\
\hline & Credit risk & 4 & 2 & 10 & 16 & 0 & 3.19 \\
\hline & Interest risk & 1 & 0 & 8 & 23 & 0 & 3.66 \\
\hline & Fn. Inst. Value & 0 & 4 & 15 & 13 & 0 & 3.28 \\
\hline & Total & 6 & 10 & 43 & 69 & $\mathbf{0}$ & 3.37 \\
\hline & $\%$ & 4.69 & 7.81 & 33.59 & 53.91 & 0 & \\
\hline \multirow{7}{*}{ 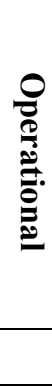 } & Environment risk & 8 & 3 & 11 & 9 & 1 & 2.75 \\
\hline & Natural resources & 22 & 3 & 4 & 12 & 1 & 2.21 \\
\hline & Operation risk & 1 & 3 & 11 & 16 & 1 & 3.41 \\
\hline & Suppliers & 3 & 4 & 10 & 14 & 1 & 3.19 \\
\hline & Technology & 1 & 2 & 10 & 21 & 3 & 3.62 \\
\hline & Total & 35 & 15 & 46 & 72 & 7 & 3.01 \\
\hline & $\%$ & 20.00 & 8.57 & 26.29 & 41.14 & 4.00 & \\
\hline \multirow{8}{*}{ 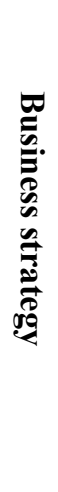 } & Market risk & 0 & 0 & 2 & 28 & 2 & 4.00 \\
\hline & Weather risk & 13 & 5 & 7 & 5 & 2 & 2.31 \\
\hline & Seasonality & 5 & 2 & 18 & 7 & 0 & 2.84 \\
\hline & $\begin{array}{l}\text { Government } \\
\text { regulation }\end{array}$ & 0 & 2 & 13 & 17 & 0 & 3.47 \\
\hline & Political risk & 3 & 6 & 15 & 8 & 0 & 2.88 \\
\hline & Cyclicality & 23 & 4 & 3 & 2 & 0 & 1.50 \\
\hline & Total & 44 & 19 & 58 & 67 & 4 & 2.83 \\
\hline & $\%$ & 22.92 & 9.90 & 30.21 & 34.90 & 2.08 & \\
\hline
\end{tabular}

$\mathrm{IN}=$ Insignificant (1), MI= Minor (2), MO= Moderate (3), M= Major (4), CA (5)= Catastrophic

\subsubsection{Analysis of Strategic Risk Management Strategies by Industry}

Table 4c presents an analysis of strategic risk management by industry. According to our analyses, companies may choose among four possible strategies to manage their risk: accept it, transfer it, reduce it or avoid the risk. Our results seem to indicate that the strategy of reducing risks was the one which was used most frequently when faced with a risk whereas the strategy of transferring the risks was almost never used by the companies in our sample. In the resources sector, the strategy of reducing risks was most often used to deal with financial or operational risks. On the other hand, companies more often chose the strategy of accepting the risks when it came to managing strategic risks while the strategy of reducing risks came second.

In the manufacturing sector, $65 \%$ of companies chose to reduce financial risks whereas $18 \%$ preferred avoiding risks. To manage operational risks, $60 \%$ of companies opted for reducing them, $20 \%$ to avoid them and $20 \%$ to accept them. Finally, $62 \%$ of companies in the service sector chose to reduce risks to manage financial risks and $27 \%$ chose to avoid them. To manage operational risks, $44 \%$ chose to reduce the risks, $33 \%$ to avoid them and $23 \%$ to accept them. Finally, accepting the risks and reducing them were the two options chosen most often to manage strategic risks. 
Table 4c. Analysis of risk management strategies by industry

Panel A- Resources

Panel B- Manufacturing

\begin{tabular}{lcccccccccc} 
& AR & TR & RR & AVR & Average & AR & TR & RR & AVR & Average \\
\hline Currency risk & 17 & 0 & 30 & 4 & 2.41 & 3 & 1 & 19 & 4 & 2.89 \\
\hline Credit risk & 9 & 0 & 35 & 7 & 2.78 & 1 & 0 & 20 & 6 & 3.15 \\
\hline Interest risk & 5 & 0 & 39 & 7 & 2.94 & 6 & 0 & 16 & 5 & 2.74 \\
\hline Fin. instrument value & 9 & 0 & 37 & 5 & 2.75 & 7 & 0 & 15 & 5 & 2.67 \\
\hline \multicolumn{1}{c}{ Total } & $\mathbf{4 0}$ & $\mathbf{0}$ & $\mathbf{1 4 1}$ & $\mathbf{2 3}$ & $\mathbf{2 . 7 2}$ & $\mathbf{1 7}$ & $\mathbf{1}$ & $\mathbf{7 0}$ & $\mathbf{2 0}$ & $\mathbf{2 . 8 6}$ \\
\hline & 19.61 & 0 & 69.12 & 11.27 & & 15.74 & 0.93 & 64.81 & 18.52
\end{tabular}

\begin{tabular}{|c|c|c|c|c|c|c|c|c|c|c|c|}
\hline \multirow{7}{*}{ 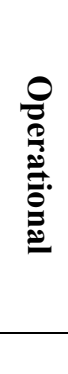 } & Environment risk & 4 & 0 & 38 & 9 & 3.02 & 5 & 0 & 14 & 8 & 2.93 \\
\hline & Natural resources & 39 & 0 & 10 & 2 & 1.51 & 16 & 0 & 7 & 4 & 1.96 \\
\hline & Operation risk & 2 & 0 & 42 & 7 & 3.06 & 1 & 0 & 21 & 5 & 3.11 \\
\hline & Suppliers & 13 & 0 & 32 & 6 & 2.61 & 3 & 0 & 19 & 5 & 2.96 \\
\hline & Technology & 4 & 0 & 36 & 11 & 3.06 & 3 & 0 & 19 & 5 & 2.96 \\
\hline & Total & 62 & $\mathbf{0}$ & 158 & 35 & 2.65 & 28 & 0 & 80 & 27 & 2.79 \\
\hline & $\%$ & 24.31 & 0 & 61.96 & 13.73 & & 20.74 & 0 & 59.26 & 20.00 & \\
\hline
\end{tabular}

\begin{tabular}{|c|c|c|c|c|c|c|c|c|c|c|c|}
\hline \multirow{8}{*}{ 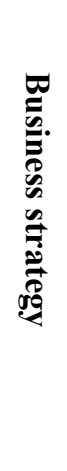 } & Market risk & 10 & 0 & 40 & 1 & 2.63 & 1 & 0 & 23 & 3 & 3.04 \\
\hline & Weather risk & 44 & 0 & 6 & 1 & 1.29 & 25 & 0 & 1 & 1 & 1.19 \\
\hline & Seasonality & 39 & 0 & 7 & 5 & 1.57 & 19 & 0 & 5 & 3 & 1.70 \\
\hline & Government regulation & 10 & 0 & 35 & 6 & 2.73 & 4 & 0 & 19 & 4 & 2.85 \\
\hline & Political risk & 6 & 0 & 38 & 7 & 2.90 & 2 & 0 & 19 & 6 & 3.07 \\
\hline & Cyclicality & 38 & 0 & 7 & 6 & 1.63 & 12 & 0 & 11 & 4 & 2.26 \\
\hline & Total & 147 & $\mathbf{0}$ & 133 & 26 & 2.12 & 63 & $\mathbf{0}$ & 78 & 21 & 2.35 \\
\hline & $\%$ & 48.04 & $\mathbf{0}$ & 43.46 & 8.50 & & 38.89 & $\mathbf{0}$ & 48.15 & 12.96 & \\
\hline
\end{tabular}

$\mathrm{AR}=$ Accept, $\mathrm{TR}=$ Transfer, $\mathrm{RR}=$ Reduce, $\mathrm{AVR}=$ Avoid 
Table 4c. Analysis of risk management strategies by industry (continued)

Panel C- Services

\begin{tabular}{|c|c|c|c|c|c|c|}
\hline \multirow{6}{*}{ 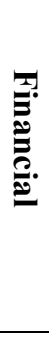 } & & AR & $\mathrm{TR}$ & RR & AVR & Average \\
\hline & Currency risk & 2 & 0 & 20 & 10 & 3.19 \\
\hline & Credit risk & 5 & 0 & 20 & 7 & 2.91 \\
\hline & Interest risk & 2 & 0 & 22 & 8 & 3.13 \\
\hline & Fin. instrument value & 6 & 0 & 17 & 9 & 2.91 \\
\hline & Total & 15 & $\mathbf{0}$ & 79 & 34 & 3.03 \\
\hline & $\%$ & 11.72 & 0 & 61.72 & 26.56 & \\
\hline
\end{tabular}

\begin{tabular}{clccccc}
\hline & 8 & 0 & 12 & 12 & 2.88 \\
\cline { 2 - 7 } & Environment risk & 21 & 0 & 12 & 9 & 2.21 \\
\cline { 2 - 7 } & Natural resources & 1 & 0 & 18 & 13 & 3.34 \\
\hline Operation risk & 7 & 0 & 15 & 10 & 2.88 \\
\cline { 2 - 7 } & Suppliers & 3 & 0 & 17 & 12 & 3.19 \\
\hline Technology & $\mathbf{4 0}$ & $\mathbf{0}$ & $\mathbf{7 4}$ & $\mathbf{5 6}$ & $\mathbf{2 . 8 6}$ \\
\hline \multicolumn{2}{c}{ Total } & 23.53 & 0 & 43.53 & 32.94 & \\
\hline
\end{tabular}

\begin{tabular}{|c|c|c|c|c|c|c|}
\hline \multirow{8}{*}{ 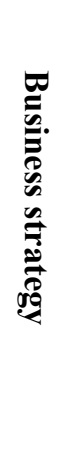 } & Market risk & 4 & 0 & 25 & 3 & 2.84 \\
\hline & Weather risk & 24 & 0 & 5 & 3 & 1.59 \\
\hline & Seasonality & 20 & 0 & 11 & 1 & 1.78 \\
\hline & Government regulation & 4 & 0 & 19 & 9 & 3.03 \\
\hline & Political risk & 6 & 0 & 16 & 10 & 2.94 \\
\hline & Cyclicality & 22 & 0 & 3 & 7 & 1.84 \\
\hline & Total & 80 & $\mathbf{0}$ & 79 & 33 & 2.34 \\
\hline & $\%$ & 41.67 & $\mathbf{0}$ & 41.15 & 17.19 & \\
\hline
\end{tabular}

$\mathrm{AR}=\mathrm{Accept}, \mathrm{TR}=$ Transfer, $\mathrm{RR}=$ Reduce, $\mathrm{AVR}=$ Avoid

\subsection{Analysis of Risk Management Practices between Corporate Strategic Options}

Table 3 shows that companies choose between three corporate strategies; these are i) a specialization, ii) a diversification, and iii) a vertical integration. In the following paragraphs, we will analyze the consequences of each one of these strategic choices on risk management practices, that is i) exposure to risk (Table 5a), ii) perceptions of the consequences of those risks (Table 5b), and iii) risk management strategies (Table $5 \mathrm{c}$ ). In order to simplify the presentation of those tables, we have chosen to report the total number of risks for each risk category (financial, operational and strategic).

\subsubsection{Analysis of Risk Exposure between Corporate Strategic Options}

Table 5a presents the distribution of risk exposure depending on the strategic choice at the corporate level. Results show that the level of exposure to risks varies according to the company's strategic choice. When the company opts for an integration strategy, it is more exposed (61\% in the category of definite risk) for risks related to this strategy, followed by companies which opted for the diversification strategy (55\%). Finally, when companies chose specialization, they saw themselves as being exposed to a definite risk in a proportion of $54 \%$. 
Table 5a. Corporate strategic options and risk exposure

\begin{tabular}{|c|c|c|c|c|c|c|c|c|c|c|c|c|c|c|c|c|c|c|c|c|c|}
\hline & $\mathbf{R}$ & & & & I & & & & $\mathbf{P}$ & & & & PR & & & & $\mathbf{C}$ & & & & TOTAL \\
\hline & $\mathbf{F}$ & $\mathbf{O}$ & B & Total & $\mathbf{F}$ & $\mathbf{O}$ & B & Total & $\mathbf{F}$ & $\mathbf{O}$ & B & Total & $\mathbf{F}$ & $\mathbf{O}$ & B & Total & $\mathbf{F}$ & $\mathbf{O}$ & B & Total & \\
\hline Specialization & 0 & 5 & 11 & 16 & 12 & 48 & 83 & 143 & 20 & 76 & 75 & 171 & 75 & 111 & 82 & 268 & 233 & 190 & 265 & 688 & 1286 \\
\hline$\%$ & $\mathbf{0}$ & 31 & 69 & 100 & 8 & 34 & 58 & 100 & 12 & 44 & 44 & 100 & 28 & 41 & 31 & 100 & 34 & 28 & 38 & 100 & \\
\hline$\%$ & & & & 1 & & & & 11 & & & & 13 & & & & 21 & & & & 54 & 100 \\
\hline Diversification & 0 & 1 & 2 & 3 & 3 & 14 & 19 & 36 & 0 & 11 & 12 & 23 & 10 & 20 & 24 & 54 & 55 & 39 & 45 & 139 & 255 \\
\hline$\%$ & $\mathbf{0}$ & 33 & 67 & 100 & 8 & 39 & 53 & 100 & $\mathbf{0}$ & 48 & 52 & 100 & 19 & 37 & 44 & 100 & 40 & 28 & 32 & 100 & \\
\hline$\%$ & & & & 1 & & & & 14 & & & & 9 & & & & 21 & & & & 55 & 100 \\
\hline Integration & 0 & 0 & 0 & $\mathbf{0}$ & 1 & 1 & 3 & 5 & 1 & 6 & 6 & 13 & 3 & 8 & 12 & 23 & 23 & 20 & 21 & 64 & 105 \\
\hline$\%$ & 0 & 0 & $\mathbf{0}$ & & 20 & 20 & 60 & 100 & 8 & 46 & 46 & 100 & 13 & 35 & 52 & 100 & 36 & 31 & 33 & 100 & \\
\hline$\%$ & & & & $\mathbf{0}$ & & & & 5 & & & & 12 & & & & 22 & & & & 61 & 100 \\
\hline Total & $\mathbf{0}$ & 6 & 13 & & 16 & 63 & 105 & & 21 & 93 & 93 & & 88 & 139 & 118 & & 311 & 249 & 331 & & \\
\hline
\end{tabular}

$\mathrm{F}=$ Financial, $\mathrm{O}=$ Operational, $\mathrm{B}=$ Business

$\mathrm{R}=$ Rare, $\mathrm{I}=$ Improbable, $\mathrm{P}=$ Possible, $\mathrm{PR}=$ Probable, $\mathrm{C}=$ Certain

4.3.2 Analysis of Risk Consequences between Corporate Strategic Options

Table $5 \mathrm{~b}$ shows a description of the consequences of risk materialization depending on the company's strategic choice. Results show that the perception of the consequences of risk materialization depends on the company's strategic choice. Thus, if we limit our analysis to "Major" and "Catastrophic" consequences, we notice a difference between specialization and diversification strategies. Thus, in the specialization strategy, consequences of strategic or operational risk materialization are perceived as more damaging than those stemming from the materialization of financial risks. This situation is reversed when we analyze the strategic option of diversification.

Differences between the three corporate strategies seem to appear mainly at the level of the distribution of consequences. In a strategy of diversification, $48 \%$ of risks have major or catastrophic consequences; this proportion reaches $46 \%$ for the two other types of strategies. It should be noted that the strategy of integration shows no risk in the "catastrophic" category whereas the strategies of diversification and specialization show respectively $5 \%$ and $2 \%$ in this category. Furthermore, these two groups of strategies show respectively $11 \%$ and $13 \%$ in the "insignificant" category whereas this proportion is only $5 \%$ in the integration group.

Table 5b. Corporate Strategic options and perceptions of risk consequences

\begin{tabular}{|c|c|c|c|c|c|c|c|c|c|c|c|c|c|c|c|c|c|c|c|c|c|}
\hline & IN & & & & MI & & & & мо & & & & $\mathbf{M}$ & & & & $\mathbf{C A}$ & & & & TOTAL \\
\hline & $\mathbf{F}$ & $\mathbf{O}$ & B & Total & $\mathbf{F}$ & $\mathbf{O}$ & B & Total & $\mathbf{F}$ & $\mathbf{O}$ & B & Total & $\mathbf{F}$ & $\mathbf{O}$ & B & Total & $\mathbf{F}$ & $\mathbf{O}$ & B & Total & \\
\hline Specialization & 4 & 49 & 84 & 137 & 23 & 31 & 51 & 105 & 146 & 141 & 161 & 448 & 170 & 190 & 208 & 568 & 1 & 19 & 12 & 32 & 1290 \\
\hline$\%$ & 3 & 36 & 61 & 100 & 22 & 30 & 48 & 100 & 33 & 31 & 36 & 100 & 30 & 33 & 37 & 100 & 3 & 59 & 38 & 100 & \\
\hline$\%$ & & & & 11 & & & & 8 & & & & 35 & & & & 44 & & & & 2 & 100 \\
\hline Diversification & 2 & 12 & 18 & 32 & 2 & 9 & 11 & 22 & 27 & 20 & 31 & 78 & 34 & 37 & 40 & 111 & 3 & 7 & 2 & 12 & 255 \\
\hline$\%$ & 6 & 38 & 56 & 100 & 9 & 41 & 50 & 100 & 34 & 26 & 40 & 100 & 31 & 33 & 36 & 100 & 25 & 58 & 17 & 100 & \\
\hline$\%$ & & & & 13 & & & & 9 & & & & 30 & & & & 43 & & & & 5 & 100 \\
\hline Integration & 1 & 1 & 3 & 5 & 1 & 4 & 6 & 11 & 13 & 12 & 16 & 41 & 13 & 18 & 17 & 48 & 0 & 0 & 0 & 0 & 105 \\
\hline$\%$ & 20 & 20 & 60 & 100 & 9 & 36 & 55 & 100 & 32 & 29 & 39 & 100 & 27 & 38 & 35 & 100 & 0 & 0 & 0 & & \\
\hline$\%$ & & & & 5 & & & & 10 & & & & 39 & & & & 46 & & & & 0 & 100 \\
\hline Total & 7 & 62 & 105 & & 26 & 44 & 68 & & 186 & 173 & 208 & & 217 & 245 & 265 & & 4 & 26 & 14 & 44 & \\
\hline
\end{tabular}

$\mathrm{F}=$ Financial, $\mathrm{O}=$ Operational, $\mathrm{B}=$ Business

$\mathrm{IN}=$ Insignificant, $\mathrm{MI}=$ Minor, $\mathrm{MO}=$ Moderate, $\mathrm{M}=$ Major, $\mathrm{CA}=$ Catastrophic 


\subsubsection{Analysis of Risk Management Strategies between Corporate Strategic Choices}

Table 5c illustrates the distribution of risk management strategies depending on the company's strategic option. Results show that the vast majority of companies seem to prefer the risk reduction option, with $64 \%$ for the vertical integration strategy, followed by the two other groups (specialization and diversification) with $53 \%$.

The second risk management option which companies seem to prefer is that of accepting the risk, with the highest proportion, $30 \%$, for the specialization group, followed by the diversification group and then by the vertical integration group with respectively $28 \%$ and $27 \%$. The last option chosen is that of risk avoidance, chosen by $19 \%$ of companies within the strategic diversification group, and to a lesser extent, at $17 \%$, by the specialization group. The vertical integration group chose this option by a proportion of only $9 \%$. It should be noted that the risk transfer option was chosen by only one company which belonged to the specialization group.

On the other hand, the results of Table 5c show that the company's strategic choice drives its approach to managing risks. Thus when a company chooses the specialization option, it chooses risk reduction in order to attenuate financial risks; it then chooses the risk avoidance option, followed by accepting the risks. The approach is almost the same when faced with a financial risk but the company chooses the strategy of accepting the risk in order to manage it; it then chooses to reduce the risk and then settles on risk avoidance.

Results also show that a diversified company will tend to opt for risk reduction to manage a financial risk; it will then choose to avoid the risk and will finally come to accept it. As for operational risks, companies which have opted to diversify seem to choose the strategy of reduction and avoidance more often. Finally, in the presence of a strategic risk, diversified companies choose risk reduction as a management strategy rather than acceptation or avoidance.

Table 5c. Corporate strategic options and risk management strategies

\begin{tabular}{|c|c|c|c|c|c|c|c|c|c|c|c|c|c|c|c|c|c|}
\hline & \multicolumn{4}{|c|}{ AR } & \multicolumn{4}{|l|}{$\mathrm{TR}$} & \multicolumn{4}{|l|}{$\mathrm{RR}$} & \multicolumn{4}{|c|}{ AVR } & \multirow[t]{2}{*}{ TOTAI } \\
\hline & $\mathbf{F}$ & $\mathbf{O}$ & B & Total & $\mathbf{F}$ & $\mathbf{O}$ & B & Total & $\mathbf{F}$ & $\mathbf{O}$ & B & Total & $\mathbf{F}$ & $\mathbf{O}$ & $\mathbf{B}$ & Total & \\
\hline Specialization & 59 & 104 & 229 & 392 & 1 & 0 & 0 & 1 & 223 & 236 & 222 & 681 & 61 & 90 & 65 & 216 & 1290 \\
\hline$\%$ & 15 & 27 & 58 & 100 & 100 & $\mathbf{0}$ & $\mathbf{0}$ & 100 & 33 & 35 & 32 & 100 & 28 & 42 & 30 & 100 & \\
\hline$\%$ & & & & 30 & & & & $\mathbf{0}$ & & & & 53 & & & & 17 & 100 \\
\hline Diversification & 10 & 17 & 43 & 70 & 0 & 0 & 0 & $\mathbf{0}$ & 45 & 44 & 47 & 136 & 13 & 24 & 12 & 49 & 255 \\
\hline$\%$ & 14 & 24 & 62 & 100 & $\mathbf{0}$ & $\mathbf{0}$ & $\mathbf{0}$ & & 33 & 32 & 35 & 100 & 27 & 49 & 24 & 100 & \\
\hline$\%$ & & & & 28 & & & & $\mathbf{0}$ & & & & 53 & & & & 19 & 100 \\
\hline Integration & 3 & 9 & 18 & 30 & 0 & 0 & 0 & $\mathbf{0}$ & 22 & 25 & 25 & 72 & 3 & 4 & 3 & 10 & 112 \\
\hline$\%$ & 10 & 30 & 60 & 100 & 0 & 0 & 0 & & 30 & 35 & 35 & 100 & 30 & 40 & 30 & 100 & \\
\hline$\%$ & & & & 27 & & & & 0 & & & & 64 & & & & 9 & 100 \\
\hline Total & 72 & 130 & 290 & & 1 & 0 & 0 & & 290 & 305 & 294 & & 77 & 118 & 80 & & \\
\hline
\end{tabular}

$\mathrm{F}=$ Financial, $\mathrm{O}=$ Operational, $\mathrm{B}=$ Business

$\mathrm{AR}=$ Accept, $\mathrm{TR}=$ Transfer, $\mathrm{RR}=$ Reduce, $\mathrm{AVR}=$ Avoid

\section{Conclusion}

In a context of heavy competition and financial and economic turmoil, companies are faced with a whole array of financial, strategic and operational risks. To better understand and face repercussions on their activities, numerous companies adopt integrated risk management systems. Corporate strategic options are an important driver for risk management practices. In fact, different strategies need different resources, priorities and know-how. They also give rise to different risks and management mechanisms (Smith, 2012). In such a context, our study aimed at analyzing the relationships between a company strategic options and its risk management approach. More specifically, our study examined if a company's corporate strategy affects its exposure level to risks, the perception of the consequences of risk materialization and finally its risk management strategy.

We chose two levels of strategic analysis. The first one was the choice of industrial sector (resources sector, manufacturing sector, services sector). The second one dealt with the choice of corporate strategies (specialization, 
diversification or vertical integration). As for the risks, we were able to identify 16 different risks which we divided into three risk categories, namely financial, operational and business risks.

Based on a sample of 110 non-financial companies listed on the Toronto Stock Exchange, our results showed that the level of risk exposure, the consequences of risk materialization and the risk management strategy vary according to the industrial sector for both individual risks and risk categories. Furthermore, our results suggest that a company's strategic option drives its risk management strategy. These results are potentially useful for senior managers and for the directors in charge of risk monitoring at the board of directors level. These results might help them in their efforts to develop better strategic plans and reinforce a proactive role in risk anticipation, good governance and efficient management of their company.

However, the paper's results should be interpreted with a number of limitations. The small number of observations in the diversification and vertical integration group limits the scope of our analyses on the link between corporate strategies and integrated risk management practices. Thus, future studies may choose to use a larger sample of companies which would, among other things, allow for a more thorough analysis of some specific risks or risk categories while widening the analysis of strategies which might eventually include strategies for growth vectors and development models.

\section{References}

Allayannis, G., \& J. Weston. (2001). The Use of Foreign Currency Derivatives and Firm Market Value. Review of Financial Studies, 14, 243-276. http://dx.doi.org/10.1093/rfs/14.1.243

American Institute of Certified Public Accountants and the Canadian Institute of Chartered Accountants. (1999). Managing Risk in the New Economy. CICA: Toronto.

Ansoff I. (1965). Corporate Strategy. McGraw-Hill, New York.

Beasley, M. S., Pagach, D. P., \& R. S. Warr. (2008). Information Conveyed in Hiring Announcements of Senior Executives Overseeing Enterprise-Wide Risk Management Processes. Journal of Accounting Auditing \& Finance, 23, 311-332.

Beasley, M. S., R. Clune, \& D. R. Hermanson. (2005). Enterprise Risk Management: An Empirical Analysis of Factors Associated with the Extent of Implementation. Journal of Accounting and Public Policy, 24, 521-531. http://dx.doi.org/10.1016/j.jaccpubpol.2005.10.001

Caldwell, J. E. (2012). A Framework for Board Oversight of Enterprise Risk. Canadian Institute of Chartered Accountants. 82 pages.

Chandler A.D. (1992). Corporate strategy, Structure and Control Methodes in the United States during the 20th Century. Industrial and Corporate Change, 1, 263-284. http://dx.doi.org/10.1093/icc/1.2.263

Collis D.J., \& Montgomery C.A. (2005). Corporate Strategy: A Resource-Based Approach. McGraw-Hill Press.

Committee of sponsoring organizations of the Treadway Commission (COSO). (2004). Enterprise Risk Management - Integrated Framework. Executive Summary. Retrieved from http://www.coso.org/documents/COSO_ERM_ExecutiveSummary.pdf

Davis R., \& Duhaime, I.M. (1992). Diversification, Vertical Integration, and Industry Analysis: New Perspective and Measurement. Strategic Management Journal, 13, 511-524. http://dx.doi.org/10.1002/smj.4250130704

Dia, M., \& D. Zeghal. (2008). Évaluation floue des profils de gestion des risques divulgués dans les rapports annuels des entreprises. Revue Canadienne des Sciences de l'administration, 25(3), i-xix. http://dx.doi.org/10.1002/cjas.70

Dobler, M. (2008). Incentives for Risk Reporting - A Discretionary Disclosure and Cheap Talk Approach. International Journal of Accounting, 43(2), 184-206. http://dx.doi.org/10.1016/j.intacc.2008.04.005

Gordon, L. A., M. P. Loeb, \& C. Y. Tseng. (2009). Enterprise Risk Management and Firm Performance: A Contingency Perspective. Journal of Accounting and Public Policy, 28, 301-327. http://dx.doi.org/10.1016/j.jaccpubpol.2009.06.006

Hoskisson R.E., \& Hitt M.A. (1990). Antecedents and Performance Outcomes of Diversification: A Review and Critique of Theoretical Perspectives. Journal of Management, 16(2), 461-509. http://dx.doi.org/10.1177/014920639001600210 
Hoyt, R. E., \& A. E. Liebenberg. (2011). The Value of Enterprise Risk Management. Journal of Risk and Insurance, 78(4), 795-822. http://dx.doi.org/10.1111/j.1539-6975.2011.01413.x

Institute of Chartered Accountants in England \& Wales (ICAEW). (2011). Reporting Business Risks: Meeting Expectations. Research Report, 79 pages.

Lajili, K., \& D. Zéghal. (2005). A Content Analysis of Risk Management Disclosures in Canadian Annual Reports. $\begin{array}{llll}\text { Canadian Journal of Administrative } & \text { Sciences, } & \text { 22(2), }\end{array}$ http://dx.doi.org/10.1111/j.1936-4490.2005.tb00714.x

Liebenberg, A. P., \& R. E. Hoyt. (2003). The determinants of Enterprise Risk Management: Evidence from the appointment of Chief Risk Officers. Risk Management and Insurance Review, 6, 37-52. http://dx.doi.org/10.1111/1098-1616.00019

Linsley, P. M., \& P. J. Shrives. (2006). Risk Reporting: a Study of Risk Disclosures in the Annual Reports of UK Companies. British Accounting Review, 38, 387-404. http://dx.doi.org/10.1016/j.bar.2006.05.002

McShane, M. K., A. Nair, \& E. Rustambekov. (2011). Does Enterprise Risk Management Increase Firm Value. Journal of Accounting Auditing and Finance, 26(4), 641-658. http://dx.doi.org/10.1177/0148558X11409160

Miller D. J. (2006). Technological Diversity, Related Diversification, and Firm Performance. Strategic Management Journal, 27(7), 601-619. http://dx.doi.org/10.1002/smj.533

Mpoyi, R.T. (2003). Vertical Integration: Strategic Characteristics and Competitive Implications. Competitiveness Review, 13(1), 44-55. http://dx.doi.org/10.1108/eb046451

Pagach, D. P., \& R. S. Warr. (2011). The Characteristics of firms that hire chief risk officers. Journal of Risk and Insurance, 78, 185-211. http://dx.doi.org/10.1111/j.1539-6975.2010.01378.x

Razali, A. R., \& I. M. Tahir. (2011). Review of the literature on Enterprise Risk Management. Business Management Dynamics, 1(5), 8-16.

Robins J., \& Wiersema, M.F. (1995). A Resource-Based Approach to the Multi-business Firm: Empirical Analysis of Portfolio Interrelationships and Corporate Financial Performance. Strategic Management Journal, 16(4), 277-299. http://dx.doi.org/10.1002/smj.4250160403

Rumet R.P. (1974). Strategy, Structure and Economic Performance. Harvard Business School Press, Boston, Mass.

Smith, K. W. (2012). 20 Questions Directors Should Ask about Strategy (3rd ed.). Canadian Institute of Chartered Accountants. 17 pages.

Smithson, C., \& B. J. Simkins. (2005). Does Risk Management Add Value? A Survey of the Evidence. Journal of Applied Corporate Finance, 17(3), 8-17. http://dx.doi.org/10.1111/j.1745-6622.2005.00042.x

Wan, H.P., Hoskisson R.E., Short J.C., \& Yiu, D.W. (2011). Resource-Based Theory and Corporate Diversification: Accomplishments and Opportunities. Journal of Management, 37(5), 1335-1368. http://dx.doi.org/10.1177/0149206310391804

Williamson O.E. (1981). The Economics of Organization: The Transaction Cost Approach. American Journal of Sociology, 87, 549-557. http://dx.doi.org/10.1086/227496 